\title{
Analysis of Prosthetic Factors Affecting Peri-Implant Health: An in vivo Retrospective Study
}

\author{
Reham N AlJasser' \\ Mohammed A AISarhan (ID) \\ Dalal H Alotaibi' \\ Saleh AIOraini' \\ Abdul Sadekh Ansari ${ }^{2}$ \\ Syed Rashid Habib (iD) ${ }^{3}$ \\ Muhammad Sohail Zafar (iD) 4,5 \\ 'Department of Periodontics and \\ Community Dentistry, College of \\ Dentistry, King Saud University, Riyadh, \\ Saudi Arabia; ${ }^{2}$ Dental University Hospital, \\ King Saud University Medical City, \\ Riyadh, Saudi Arabia; ${ }^{3}$ Department of \\ Prosthetic Dental Sciences, College of \\ Dentistry, King Saud University, Riyadh, \\ Saudi Arabia; ${ }^{4}$ Department of Restorative \\ Dentistry, College of Dentistry, Taibah \\ University, Al Madinah, Al Munawwarah, \\ 4I3II, Saudi Arabia; ${ }^{5}$ Department of \\ Dental Materials, Islamic International \\ Dental College, Riphah International \\ University, Islamabad, 44000, Pakistan
}

Correspondence: Syed Rashid Habib Department of Prosthetic Dental Sciences, College of Dentistry, King Saud University, Riyadh, Saudi Arabia

Tel +966-| -467 7325

Fax +966-I-4678548

Email syhabib@ksu.edu.sa
Objective: To investigate and compare the various restorative and prosthetic parameters affecting peri-implant tissues' health following dental implant placement and functional loading.

Methods: A total of 484 dental implants (length $>6 \mathrm{~mm}$, non-turned, $2-3$ piece, titanium Straumann) were evaluated for patients (male=271; female=213). Study variables such as patient's age, gender, implant restoration/crown type, crown retention, and implant crown status were assessed against various periodontal parameters (periodontal pocket depth (PPD), plaque index (PI), bleeding on probing (BOP), gingival color, and crestal bone level). All the data were analyzed using the SPSS software.

Results: Out of all the investigated dental implants, 201 (42\%) of the implants investigated presented with BOP $>$ one-site of the peri-implant mucosa (peri-implant mucositis), 115 $(23.76 \%)$ presented with peri-implant marginal bone loss. PPD value was significantly lower in good crown status $(\mathrm{p}<0.0001)$. Majority of the patients with good crown status had no plaque accumulation based on the PI scores (52.7\%). Only $35 \%$ of the patients whose crown status was good were having BOP when compared with $65 \%$ who did not have any BOP recorded. Gingival color (pale pink and red) showed statistically significant association with crown type (porcelain fused to metal v/s all ceramic) $(\mathrm{p}=0.005)$. Most of patients with crown status good had no change in their radiographic findings $(94 \%)$ compared to only $6 \%$ who had implant threads exposed $(\mathrm{p}<0.0001)$.

Conclusion: Optimal design of Implant prosthetic factors are vital for avoiding the development of peri-implant mucositis/peri-implantitis and must be considered during treatment planning while restoring dental implants.

Keywords: peri-implantitis, dental implants, implants, implant prosthesis, implant health, implant mucositis

\section{Introduction}

Dental implants are preferred for replacement of missing teeth and gained global popularity due to their high overall success rate in the clinical practice. ${ }^{1,2}$ However, the overall success rate of dental implants is associated with the health of periimplant tissues and lowered by the complications of peri-implant mucositis and peri-implantitis. ${ }^{3}$ Peri-implantitis is a condition which is poorly understood and difficult to manage, therefore it is essential to better prevent it with careful control of all phases of the treatment process. ${ }^{4}$ The health and quality of peri-implant soft tissues is influenced by many factors. For example, the presence or absence of 
adequate keratinized mucosa surrounding an implant mainly affects the health of peri-implant soft-tissues. Similarly, various aspects related to the prosthodontic treatments such as poor treatment planning, impression taking, laboratory decisions, temporization, poorly designed restorations and cementation may have longterm consequences due to contamination of the implant surfaces and influencing the health of peri-implant tissues. ${ }^{5}$ The manner in which a dental implant is restored significantly contributes to the long-term prognosis and course of peri-implant diseases. ${ }^{6}$

The prevalence of peri-implantitis is about $12 \%$ to $22 \%$ where nearly $40 \%$ of these patients suffer from the periimplant mucositis. Therefore, peri-implant disease is becoming a source of growing concern among oral health professionals. ${ }^{7}$ Although numerous hypotheses on the etiology of peri-implant mucositis and peri-implantitis have been proposed, the major cause of peri-implant diseases is reported infectious in nature. ${ }^{4}$ Accordingly, emphasis on the correlation of pathogenic bacteria contributing to the progression of the peri-implantitis is important. Although the bacterial plaque and peri-implant mucositis are considered, a clear association with the peri-implantitis has not been demonstrated yet. ${ }^{6}$ In a recent consensus meeting, ${ }^{8}$ it has been described that periimplant pathology has a multifactorial etiology comprised of implant associated factors (materials, design, and surface properties), clinician factors (prosthodontic experience, and surgical skill), and patient related factors (general health, bone quality medications, oral hygiene, and smoking). ${ }^{8}$

Implant prosthesis design plays an important role in determining the patient's risk for developing peri-implant mucositis and peri-implantitis. ${ }^{9}$ Prosthetic factors such as presence of residual cement, ill-fitting prosthetic components, insufficient crown margins on implant abutments, abutment height, abutment-implant connections, prosthesis contours, access for oral hygiene, and management of occlusal forces are potential etiologic factors leading to peri-implantitis. Previous literatures ${ }^{10,11}$ have identified a correlation between plaque and peri-implantitis however, negated the significance of prosthetic parameters. To minimize the likelihood of developing peri-implant diseases, the risk factors associated with implant failures require thorough evaluation prior to implant procedures and after implant loading. Therefore, the aim of the present in vivo study was to assess the role of prosthetic or restorative factors affecting peri-implant health. In addition, various restorative risk factors associated with peri-implantitis were evaluated by observing changes in several periodontal parameters over a period of three years following implant placement and functional loading.

\section{Materials and Methods}

The present study was carried out following the Helsinki Declaration of 1975 (revised 2013) after approval from the Ethics committee, Institutional Review Board, King Saud University, Riyadh, Saudi Arabia (Ref: 87563). The present study recruited patients who received conventional dental implants (Bone level, length $>6 \mathrm{~mm}$, titanium, Straumann, Switzerland) to replace one or more missing teeth. All the treatment procedures were performed at the Department of Periodontics, College of Dentistry, King Saud University, Riyadh, Saudi Arabia during a period from year 2015 to 2018. A random sampling method was applied to recruit subjects with one or more missing teeth, restored using single implant-supported crowns with a functional occlusal loading for six months or more at the time of evaluation. The criteria set by Konstantinidis et $\mathrm{al}^{12}$ and Schwarz et $\mathrm{al}^{13}$ for patient selection were followed. All the procedures and research objectives were explained to every patient and informed consent was obtained for participating in this study.

Any patients with any uncontrolled systemic diseases (such as osteoporosis, diabetes HbAlc $>7$,); smoking; breastfeeding or pregnant women; consumption of medications that may affect bone metabolism and mucosal healing (such as anti-resorptive drugs, steroids); use of antibiotics within past eight weeks; any restorations obstructing the calculation of periodontal pocket depths (PPD), and the absence of baseline radiographic data were excluded. Out of 2045 screened records, 213 female patients and 271 male patients (age 26-87 years) fulfilling the section criteria were included. Among the selected patients, a total of 484 dental implants were evaluated for identifying risk indicators by assessing several periodontal parameters.

\section{Study Variables and Clinical Measurements}

In the present study, variables including patient's age, gender, implant restoration/crown type (porcelain fused to metal [PFM], all ceramic), crown retention type (cement retained, screw retained), implant-crown status (good [adequate emergence profile and contours], fair [inadequate emergence profile and contours], fractured [crown fractured], and overcontoured [bulky gingival and axial contours]) were assessed against the periodontal parameters. 
For each implant site, the periodontal parameters were evaluated by inserting a plastic probe (11 Colorvue Probe, HuFriedy) into the gingival sulcus with gentle pressure $\leq$ $0.25 \mathrm{Ncm}$. A total of six measurements (three points at buccal and lingual sides each) were taken by placing the probe parallel to the crown at midbuccal and midlingual points and 10 degrees tilted inward at the proximal points. All measurements were taken at the nearest $\mathrm{mm}$ shown on the probe. ${ }^{3}$ Implant sites showing PPD $6 \mathrm{~mm}$ or greater, bleeding on probing (BOP), and attachment loss/bone loss of $2.5 \mathrm{~mm}$ or greater were scored as having peri-implantitis. BOP was observed in terms of absence $(-)$ or presence $(+)$ of bleeding at the probing site following PPD measurement. ${ }^{14}$ The modified plaque index $(\mathrm{PI})^{15}$ was used to assess the plaque scores (score 0- No detection of plaque; score 1- plaque only recognized by running a probe across the smooth marginal surface of the implant; score 2- plaque visible to the naked eye; score 3-abundance of soft matter). Gingival consistency and color were assessed through direct visual evaluation, and determined by the visible area between the gingival marginal level and the interproximal papillae, as redness is an indication for inflammation and pink color is an indication of gingival health. ${ }^{16}$

To evaluate the bone loss around implants, standard periapical radiographs were obtained during clinical examination and compared with the baseline radiographs obtained at prosthesis insertion to confirm bone levels around each implant. ${ }^{17}$ For accurate assessment and standardization, we scanned all radiographs (resolution: 1200 dpi), and analyzed using an image analysis software (Image JV 1.49, Research Services Branch, National Institute of Health, Bethesda, MD, USA). To calibrate the pixel $/ \mathrm{mm}$ ratio, the length of implant was used as a fixed reference point to counteract any potential radiographic distortion. ${ }^{18}$ To assess the bone loss around each implant, the distance between the most coronal bone-toimplant interface and the implant shoulder was radiographically calculated parallel to the implant's long axis distally and mesially. The investigator who was blinded to the whole process performed all radiographic calculations to avoid operator dependent bias.

The implant crown characteristics were assessed with visual examination by the blinded examiner and the crown status was scored as "Good" when the crown was with adequate margins, emergence profile and contours; it was scored as "Fair" when there were inadequate margins, emergence profile and contours. Similarly, the fractured crowns were scored as "Fractured" and the bulky contours were scored as "Overcontoured".

\section{Data Analysis}

The obtained data was evaluated using SPSS (v.24, IBM Inc., Chicago, IL, USA). Study variables such as patient's age group, gender, crown type, crown retention type and crown status were analyzed. The quantitative outcome variable PPD, categorical outcome variables including PI, BOP, gingival color, consistency, and radiographic bone loss were described using the mean, standard deviation, frequencies and percentages. Student's $t$-test and one-way ANOVA were applied to analyze mean of PPD relative to the categorical study variables. The association between the categorical study and outcome variables was evaluated using Pearson's Chi-square test. P-value of $<0.05$ was used to report the statistical significance of the results.

\section{Results}

Out of total 2045 screened patients' records, a total 213 (48.1\%) female and 271 (51.2\%) male patients aged between 26 to 87 years (mean age $=60 \pm 8.6$ years) were included following the above-mentioned selection criteria. Accordingly, we examined a total of 484 dental implants including 251 (56\%) placed in female patients and 233 (49\%) placed in male patients. The clinical examination revealed BOP on more than one site of the peri-implant mucosa in 201 (42\%) implants and therefore were counted as suffering from peri-implant mucositis. Further detailed evaluation of periapical radiographs revealed marginal bone loss in $115(23.76 \%)$ implants confirming the diagnosis of peri-implantitis.

In the present study, the mean PPD value was significantly lower in subjects whose crown status was good compared to the subjects whose crown status was fair, fractured or over-contoured $(p<0.0001)$ (Table 1). The distribution of PI (Yes/No) across the study variables showed statistically significant association with crown status. The majority of the patients with good crown status had no plaque accumulation based on the PI scores (52.7\%) compared to $47.3 \%$ with positive PI. Patients with crown status fair had $100 \%$ PI positive and $86 \%$ of patients with crown status over-contoured had positive PI which indicated a high statistically significant association between crown status and PI $(p<0.0001)$ (Table 2). Furthermore, distribution of BOP (Yes/No), across the study variables also showed a statistically significant association with crown status. Only $35 \%$ of the patients whose crown status was good were having BOP compared to $65 \%$ who did not have any BOP recorded. 
Table I Comparison of Mean Values of Periodontal Pocket Depth in Relation to the Study Variables $(\mathrm{N}=484)$

\begin{tabular}{|c|c|c|c|c|}
\hline Variables & Groups & Mean (SD) & $\begin{array}{c}\text { F-valuel } \\
\text { t-value }\end{array}$ & p-value \\
\hline Age (yrs.) & $\begin{array}{c}\leq 40 \\
41 \text { to } 60 \\
>60\end{array}$ & $\begin{array}{l}4.64(2.0) \\
4.68(2.1) \\
4.70(2.1)\end{array}$ & 0.034 & 0.966 \\
\hline Gender & $\begin{array}{l}\text { Male } \\
\text { Female }\end{array}$ & $\begin{array}{l}4.46(2.1) \\
4.87(2.1)\end{array}$ & -1.969 & 0.050 \\
\hline Restoration & $\begin{array}{c}\text { PFM } \\
\text { All Ceramic }\end{array}$ & $\begin{array}{l}4.61(2.0) \\
5.15(2.4)\end{array}$ & -1.873 & 0.062 \\
\hline Retention & $\begin{array}{l}\text { Cement } \\
\text { Screw }\end{array}$ & $\begin{array}{l}4.79(2.1) \\
4.58(2.1)\end{array}$ & 1.060 & 0.289 \\
\hline $\begin{array}{l}\text { Crown } \\
\text { status }\end{array}$ & $\begin{array}{c}\text { Good } \\
\text { Fair } \\
\text { Fractured } \\
\text { Over-contoured }\end{array}$ & $\begin{array}{l}3.24(0.89) \\
4.01(0.49) \\
6.80(0.40) \\
6.73(1.93)\end{array}$ & 319.06 & $<0.0001$ \\
\hline
\end{tabular}

Similarly, $95.1 \%$ of subjects whose crown status was fractured and $38 \%$ whose crown status was overcontoured had BOP when compared with $4.9 \%$ and $5.4 \%$ who did not had BOP which indicates high statistically significant association between crown status and BOP $(p<0.0001)$ (Table 3).

In regard to gingival color (pale pink and red) and its association with all the study variables, it showed a statistically significant association with crown type (PFM v/s all ceramic), crown status (good, fair, fractured and over-contoured) and crown type (screw v/s cement retained). The majority of patients with PFM crowns $(67.5 \%)$ had pale pink gingival color when compared to $49.2 \%$ of patients with all ceramic crowns. This difference between PFM and all ceramic crowns was statistically significant $(\mathrm{p}=0.005)$. The crown status was also significantly associated with gingival color, whereas $98.2 \%$ of patients with good crown status had pale pink color compared to patients with over-contoured crown status only $20.9 \%$ had pale pink gingival color $(\mathrm{p}<0.0001)$ (Table 4). The crown status that was observed as good, $85.5 \%$ of the patients had "firm" consistency of gingiva, whereas $100 \%$, $100 \%$ and $95.3 \%$ of the patients with crown status fair, fractured and over-contoured had consistency as "edematous", this was highly significant $(\mathrm{p}<0.0001)$. In contrast, it was observed that $74 \%$ of patients with screw retained crowns had pale pink gingiva compared to only $56.1 \%$ of those received cement retained crown which was statistically significant $(\mathrm{p}<0.0001)$ (Table 5 ).

Finally, the radiographic examination revealed that $94 \%$ of patients with good crown status had no change in their radiographic findings compared to only $6 \%$ who had implant threads exposed. Whereas $73.8 \%$ of patients with crown status fair, $70 \%$ of patients with crown status fractured and $59.7 \%$ of patients with crown status over-contoured had different level of implant threads exposure when compared with $26.2 \%, 30 \%$ and $40.3 \%$ did not have any change in their radiographic findings which indicates a statistically significant association between crown status and alveolar bone resorption in term of thread exposure $(\mathrm{p}<0.0001)$ (Table 6).

Table 2 Association Between Periodontal Index and Other Study Variables ( $N=484)$

\begin{tabular}{|c|c|c|c|c|c|}
\hline \multirow[t]{2}{*}{ Variables } & \multirow[t]{2}{*}{ Groups } & \multicolumn{2}{|c|}{ PI Mean (SD) } & \multirow[t]{2}{*}{$X^{2}$-value } & \multirow[t]{2}{*}{ p-value } \\
\hline & & Yes & No & & \\
\hline Age (yrs.) & $\begin{array}{c}\leq 40 \\
41 \text { to } 60 \\
>60\end{array}$ & $\begin{array}{c}84(63.2) \\
125(63.8) \\
96(63.2)\end{array}$ & $\begin{array}{l}49(36.8) \\
71(36.2) \\
56(36.8)\end{array}$ & 0.019 & 0.990 \\
\hline Gender & $\begin{array}{l}\text { Male } \\
\text { Female }\end{array}$ & $\begin{array}{l}134(63.2) \\
127(63.8)\end{array}$ & $\begin{array}{l}78(36.8) \\
72(36.2)\end{array}$ & 0.017 & 0.898 \\
\hline Restoration & $\begin{array}{c}\text { PFM } \\
\text { All Ceramic }\end{array}$ & $\begin{array}{c}260(61.9) \\
45(73.8)\end{array}$ & $\begin{array}{c}160(38.1) \\
16(26.2)\end{array}$ & 3.232 & 0.180 \\
\hline Retention & $\begin{array}{l}\text { Cement } \\
\text { Screw }\end{array}$ & $\begin{array}{l}139(63.8) \\
166(63.1)\end{array}$ & $\begin{array}{l}79(36.2) \\
97(36.9)\end{array}$ & 0.021 & 0.242 \\
\hline Crown status & $\begin{array}{c}\text { Good } \\
\text { Fair } \\
\text { Fractured } \\
\text { Over-contoured }\end{array}$ & $\begin{array}{c}133(47.3) \\
61(100) \\
0 \\
111(86)\end{array}$ & $\begin{array}{c}148(52.7) \\
0 \\
10(100) \\
18(14)\end{array}$ & 112.33 & $<0.0001$ \\
\hline
\end{tabular}


Table 3 Association Between Bleeding on Probing and Other Study Variables ( $N=484)$

\begin{tabular}{|c|c|c|c|c|c|}
\hline \multirow[t]{2}{*}{ Variables } & \multirow[t]{2}{*}{ Groups } & \multicolumn{2}{|c|}{ BOP Mean (SD) } & \multirow[t]{2}{*}{$X^{2}$-value } & \multirow[t]{2}{*}{ p-value } \\
\hline & & Yes & No & & \\
\hline Age (yrs.) & $\begin{array}{c}\leq 40 \\
41 \text { to } 60 \\
>60\end{array}$ & $\begin{array}{l}27(46.6) \\
39(53.4) \\
22(36.7)\end{array}$ & $\begin{array}{l}31(53.4) \\
34(46.6) \\
38(63.3)\end{array}$ & 3.730 & 0.155 \\
\hline Gender & $\begin{array}{l}\text { Male } \\
\text { Female }\end{array}$ & $\begin{array}{c}34(43) \\
42(50.6)\end{array}$ & $\begin{array}{c}45(57) \\
4 I(49.4)\end{array}$ & 0.930 & 0.335 \\
\hline Restoration & $\begin{array}{c}\text { PFM } \\
\text { All Ceramic }\end{array}$ & $\begin{array}{c}83(45.6) \\
5(55.6)\end{array}$ & $\begin{array}{c}99(54.4) \\
4(44.4)\end{array}$ & 0.342 & 0.559 \\
\hline Retention & $\begin{array}{l}\text { Cement } \\
\text { Screw }\end{array}$ & $\begin{array}{c}46(50) \\
42(42.4)\end{array}$ & $\begin{array}{c}46(50) \\
57(57.6)\end{array}$ & 1.102 & 0.294 \\
\hline Crown status & $\begin{array}{c}\text { Good } \\
\text { Fair } \\
\text { Fractured } \\
\text { Over-contoured }\end{array}$ & $\begin{array}{c}49(35) \\
13(45) \\
39(95.1) \\
167(38)\end{array}$ & $\begin{array}{c}91(65) \\
10(100) \\
2(4.9) \\
3(5.4)\end{array}$ & 55.152 & $<0.0001$ \\
\hline
\end{tabular}

Table 4 Association Between Gingival Color and Other Study Variables ( $N=484)$

\begin{tabular}{|c|c|c|c|c|c|}
\hline \multirow[t]{2}{*}{ Variables } & \multirow[t]{2}{*}{ Groups } & \multicolumn{2}{|c|}{ Gingival Color Mean (SD) } & \multirow[t]{2}{*}{$X^{2}$-value } & \multirow[t]{2}{*}{ p-value } \\
\hline & & Pale Pink & Redness & & \\
\hline Age (yrs.) & $\begin{array}{c}\leq 40 \\
41 \text { to } 60 \\
>60\end{array}$ & $\begin{array}{c}88(66.2) \\
129(65.2) \\
98(64.5)\end{array}$ & $\begin{array}{l}45(33.8) \\
69(34.8) \\
54(35.5)\end{array}$ & 0.090 & 0.956 \\
\hline Gender & $\begin{array}{l}\text { Male } \\
\text { Female }\end{array}$ & $\begin{array}{l}148(69.5) \\
123(61.5)\end{array}$ & $\begin{array}{l}65(30.5) \\
77(38.5)\end{array}$ & 2.914 & 0.088 \\
\hline Restoration & $\begin{array}{c}\text { PFM } \\
\text { All Ceramic }\end{array}$ & $\begin{array}{c}285(67.5) \\
30(49.2)\end{array}$ & $\begin{array}{c}137(32.5) \\
31(50.8)\end{array}$ & 7.916 & 0.005 \\
\hline Retention & $\begin{array}{l}\text { Cement } \\
\text { Screw }\end{array}$ & $\begin{array}{l}\mid 44(56.1) \\
19 \mid(74.5)\end{array}$ & $\begin{array}{c}174(83.9) \\
94(35.5)\end{array}$ & 0.123 & $<0.0001$ \\
\hline Crown status & $\begin{array}{c}\text { Good } \\
\text { Fair } \\
\text { Fractured } \\
\text { Over-contoured }\end{array}$ & $\begin{array}{c}278(98.2) \\
0 \\
10(100) \\
27(20.9)\end{array}$ & $\begin{array}{c}5(1.8) \\
61(100) \\
0 \\
102(79.1)\end{array}$ & 367.235 & $<0.0001$ \\
\hline
\end{tabular}

\section{Discussion}

Recent advancements in the field of dentistry have made the replacement of missing teeth by means of dental implants a common and successful treatment modality. Success of dental implant depends on numerous systemic and local factors affecting peri-implant tissues healing. There are various factors including patient's systemic health, tissues contours, use and care of prosthesis, implant-abutment interface, operative procedures for implant insertion, and prosthesis design. For example, implant failures may be either early failure due to failure to establish osseointegration initially during wound healing period or late failure can occur after occlusal loading due to the breakdown of osseointegration. Considering the significance of osseointegration, various investigators focused in enhancing the implant surface bioactivity and osseointegration. ${ }^{19-22}$ Therefore, to avoid such undesirable outcomes, a careful assessment of various factors that contribute to the implant failure is crucial. This present retrospective study was aimed to assess the restorative/ 
Table 5 Association Between Gingival Consistency and Other Study Variables ( $N=484)$

\begin{tabular}{|c|c|c|c|c|c|}
\hline \multirow[t]{2}{*}{ Variables } & \multirow[t]{2}{*}{ Groups } & \multicolumn{2}{|c|}{ Consistency Mean (SD) } & \multirow[t]{2}{*}{$X^{2}$-value } & \multirow[t]{2}{*}{ p-value } \\
\hline & & Edematous & Firm & & \\
\hline Age (yrs.) & $\begin{array}{c}\leq 40 \\
41 \text { to } 60 \\
>60\end{array}$ & $\begin{array}{l}65(48.9) \\
98(49.5) \\
72(47.4)\end{array}$ & $\begin{array}{c}68(51.1) \\
100(50.5) \\
80(52.6)\end{array}$ & 0.159 & 0.924 \\
\hline Gender & $\begin{array}{l}\text { Male } \\
\text { Female }\end{array}$ & $\begin{array}{c}94(44.1) \\
105(52.5)\end{array}$ & $\begin{array}{l}119(55.9) \\
95(47.5)\end{array}$ & 2.893 & 0.089 \\
\hline Restoration & $\begin{array}{c}\text { PFM } \\
\text { All Ceramic }\end{array}$ & $\begin{array}{c}20 \mathrm{I}(47.6) \\
34(55.7)\end{array}$ & $\begin{array}{c}22 \mid(52.4) \\
27(44.3)\end{array}$ & 1.402 & 0.236 \\
\hline Retention & $\begin{array}{l}\text { Cement } \\
\text { Screw }\end{array}$ & $\begin{array}{l}116(53.2) \\
119(44.9)\end{array}$ & $\begin{array}{l}102(46.8) \\
146(55.1)\end{array}$ & 3.303 & 0.069 \\
\hline Crown status & $\begin{array}{c}\text { Good } \\
\text { Fair } \\
\text { Fractured } \\
\text { Over-contoured }\end{array}$ & $\begin{array}{c}41(14.5) \\
61(100) \\
10(100) \\
123(95.3)\end{array}$ & $\begin{array}{c}242(85.5) \\
0(0) \\
0(0) \\
6(4.7)\end{array}$ & 319.758 & $<0.0001$ \\
\hline
\end{tabular}

Table 6 Association Between Radiographic Findings and Other Study Variables (N=484)

\begin{tabular}{|c|c|c|c|c|c|c|c|c|}
\hline \multirow[t]{2}{*}{ Variables } & \multirow[t]{2}{*}{ Groups } & \multicolumn{5}{|c|}{ Thread Exposed in Radiographic Findings Mean (SD) } & \multirow[t]{2}{*}{$X^{2}$-value } & \multirow[t]{2}{*}{ p-value } \\
\hline & & None & I Thread & 2 Threads & 3 Threads & $\begin{array}{l}4 \text { and } 5 \\
\text { Threads }\end{array}$ & & \\
\hline Age (yrs.) & $\begin{array}{c}\leq 40 \\
41 \text { to } 60 \\
>60\end{array}$ & $\begin{array}{c}97(72.9) \\
138(69.7) \\
102(67.1)\end{array}$ & $\begin{array}{l}6(4.5) \\
7(3.5) \\
4(2.6)\end{array}$ & $\begin{array}{c}8(6) \\
19(9.6) \\
14(9.2)\end{array}$ & $\begin{array}{l}17(12.8) \\
21(10.6) \\
21(13.8)\end{array}$ & $\begin{array}{c}5(3.8) \\
13(6.6) \\
11(7.2)\end{array}$ & 4.774 & 0.781 \\
\hline Gender & $\begin{array}{c}\text { Male } \\
\text { Female }\end{array}$ & $\begin{array}{l}\text { I57 (73.7) } \\
\text { I35 (67.5) }\end{array}$ & $\begin{array}{l}6(2.8) \\
10(5)\end{array}$ & $\begin{array}{c}14(6.6) \\
21(10.5)\end{array}$ & $\begin{array}{c}26(12.2) \\
19(9.5)\end{array}$ & $\begin{array}{l}10(4.7) \\
15(7.5)\end{array}$ & 5.743 & 0.219 \\
\hline Restoration & $\begin{array}{c}\text { PFM } \\
\text { All Ceramic }\end{array}$ & $\begin{array}{c}300(71.1) \\
37(60.7)\end{array}$ & $\begin{array}{l}15(3.6) \\
2(3.3)\end{array}$ & $\begin{array}{l}38(9) \\
3(4.9)\end{array}$ & $\begin{array}{l}49(11.6) \\
10(16.4)\end{array}$ & $\begin{array}{l}20(4.7) \\
9(14.8)\end{array}$ & II.792 & $<0.0001$ \\
\hline Retention & $\begin{array}{l}\text { Cement } \\
\text { Screw }\end{array}$ & $\begin{array}{l}149(68.3) \\
188(70.9)\end{array}$ & $\begin{array}{l}8(3.7) \\
9(3.4)\end{array}$ & $\begin{array}{l}20(9.2) \\
21(7.9)\end{array}$ & $\begin{array}{l}29(13.3) \\
30(11.3)\end{array}$ & $\begin{array}{l}12(5.5) \\
17(6.4)\end{array}$ & 0.911 & $<0.0001$ \\
\hline Crown status & $\begin{array}{c}\text { Good } \\
\text { Fair } \\
\text { Fractured } \\
\text { Over-contoured }\end{array}$ & $\begin{array}{c}266(94) \\
16(26.2) \\
3(30) \\
52(40.3)\end{array}$ & $\begin{array}{l}7(2.5) \\
4(6.6) \\
2(20) \\
4(3.1)\end{array}$ & $\begin{array}{c}6(2.1) \\
13(2 \mid .3) \\
4(40) \\
18(14)\end{array}$ & $\begin{aligned} 2 & (0.7) \\
20 & (32.8) \\
1 & (10) \\
36 & (27.9)\end{aligned}$ & $\begin{array}{c}2(0.7) \\
8(13.1) \\
0 \\
19(14.7)\end{array}$ & 223.699 & $<0.0001$ \\
\hline
\end{tabular}

prosthetic factors that affect the survival of Straumann dental implants in Saudi population for three years. A total of 484 dental implants were evaluated for identifying risk indicators by assessing several periodontal parameters such as PPD, BOP and PI.

In the study, the mean PPD, BOP and PI were significantly associated with the status of the definitive prosthesis. It was found that PPD was lower in subjects whose crown status was good (with adequate axial and gingival contours) when compared with the subjects whose crown status was fair (with inadequate axial and gingival contours), fractured and over-contoured crowns. These results are in accordance with Katafuchi el $\mathrm{al}^{23}$ who reported that a greater peri-implant bone loss and higher prevalence of peri-implantitis in patients having implant crown emergence profile greater than 30 degrees. Similarly, the distribution of PI (Yes/No) across the study variables showed a statistically significant association with crown status. In 
terms of PI scores, the majority of the patients with good crown status had no plaque accumulation (52.7\%) compared to $47.3 \%$ with positive PI scores. Patients with crown status fair had $100 \%$ PI positive scores and $86 \%$ of patients with crown status over-contoured had positive PI which suggested a high statistically significant association between crown status and PI $(\mathrm{p}<0.0001)$.

When BOP was measured to recognize presence of inflammation of soft tissues around dental implants, it was observed that $42 \%$ of sites had positive BOP around implants, which is in accordance with previously published study by Gerber et al. ${ }^{24}$ French et $\mathrm{al}^{25}$ used modified sulcular bleeding index and found that BOP is associated with mucositis. In a similar study by Buser et $\mathrm{al}^{26}$ using Mombelli's bleeding index which reported that on mere punctuating, bleeding spots suggests injury to the periimplant supporting tissues while the Mombelli's class 2 score indicates mucositis. Further it was concluded that mucositis does not necessarily progress to peri-implantitis over time when adequate plaque control measures are undertaken. ${ }^{15}$ Similarly, Van Velzen et al ${ }^{27}$ used the same index as Buser et $\mathrm{al}^{26}$ and found BOP at $20 \%$ of the implant sites. Stoker et $\mathrm{al}^{28}$ reported BOP in $14 \%$ of the sites examined. The BOP positive sites reported in this study were relatively higher compared to the previously published studies ${ }^{14-16,24}$ and this could be due to the difference in the indices used to record the BOP. In the current study BOP was assessed as present or absent, whereas other published studies used more specific bleeding on probing indices.

In terms of association of gingival color, soft tissue consistency with all the study variables, a statistically significant relation with crown type (PFM v/s all ceramic), crown status (good, fair, fractured and over-contoured) and crown retention (screw $\mathrm{v} / \mathrm{s}$ cement retained) were observed. The majority of patients with PFM crowns and good crown status had pale pink color and firm consistency of soft tissues around implants as compared to implants with all ceramic crowns and fair or over contoured crowns. In contrast, the majority of patients with screw retained crowns $(74.5 \%)$ had pale pink gingiva as compared to those received cement retained crowns (56.1\%). Similar findings were reported by Weber et $\mathrm{al}^{29}$ comparing peri-implant tissue interfaces in terms of screw and cemented single-tooth implants. It was concluded that cemented implant crowns had increased PI, sulcus bleeding index, and BOP scores. Similarly, according to Dalago et $\mathrm{al}^{30}{ }^{30}$ sites with cemented restorations were at 3.6 times greater risk for peri-implantitis than sites with screwretained prostheses. In addition, a study by Wilson ${ }^{31}$ notes that excess dental cement deposits were associated with signs of peri-implant lesions in $81 \%$ of cases.

One of the interesting findings observed in the study was the impact of keratinized tissue width (KTW) around dental implants, which was highlighted in many systematic reviews. $^{32-36}$ In the present study, sites with $<2 \mathrm{~mm}$ width of keratinized tissue showed significantly more edematous soft tissues compared to those with $>2 \mathrm{~mm}$ KTW. These results are in accordance with Souza et $\mathrm{al}^{37}$ who found that implant sites with $<2 \mathrm{~mm}$ KTW showed more inflammation.

Finally, radiographic changes were assessed as having no change in bone level and implant threads exposed. The patients with the good crown status had no change in their radiographic findings (94\%) compared to only $6 \%$ who had implant threads exposed. Majority of patients with crown status fair, fractured or over contoured had different levels of implant threads' exposure which indicates a statistically significant association between crown status and alveolar bone resorption. Similarly, poor oral hygiene and positive PI were significantly associated with radiographic thread exposure. These findings suggest that failure to control patient's oral hygiene may be a risk factor contributing to the development of inflammation of soft tissues around the implant, leading to bone loss and consequently implant failure. Furthermore, the present study findings revealed that, the lack of a minimum of $2 \mathrm{~mm}$ of KTW is associated with radiographic implant thread exposure. Also, Bengazi et $\mathrm{al}^{38}$ reported a higher crestal bone resorption and apical soft tissue positioning of implants placed in areas with insufficient KTW. Similarly, a recent study by Van Ekeren et $\mathrm{al}^{39}$ reported that placing dental implants in an initial KTW of $2 \mathrm{~mm}$ or more reduced crestal bone change significantly.

Inability to adequately remove microbial biofilm or plaque, by the patient and/or dental professional, has been associated with the occurrence of peri-implant diseases. Thus, proper restoration/prostheses design which offers easy plaque control plays an important role in preventing these conditions. In implant therapy, convex or overcontoured emergence profiles have been found a potential risk factor for peri-implantitis. Therefore, the design of any implant restoration should allow access that supports optimal oral hygiene around implant sites. Therefore, when placing and restoring an implant, various factors such as oral hygiene status, keratinized tissue width, available bone, and final prosthesis design must 
be considered. The present study reported that overlooking these factors may impact negatively on dental implant's long-term success.

Several limitations had been observed in present study, which include mainly inherent limitations of retrospective studies and inconsistent results from using different indices and tools in the methodology. In addition, the lack of follow up due to the retrospective design can affect the observation of a true association between different studied variables and outcomes measured. Additional limitation can be explained by collecting the present sample from one institute which cannot be highly efficient to translate the present findings to whole population of patients with implants.

\section{Conclusion}

Implant prosthesis design plays an important role in determining the patient's risk for developing peri-implant mucositis and peri-implantitis. Prosthetic design elements such as abutment height, abutment/implant interface, prosthesis contours, retained excess cement, access for oral hygiene and management of occlusal forces are important and must be considered while restoring implants. With careful treatment planning, optimal restoration design, and regular follow-up visits, we can deliver a successful implant outcome by reducing the risk of developing the peri-implant diseases.

\section{Acknowledgments}

The authors extend their appreciation to the Deanship of Scientific Research at King Saud University for funding this work through research group no. RG-1441-498.

\section{Disclosure}

The authors report no conflicts of interest in this work.

\section{References}

1. Sakka S, Baroudi K, Nassani MZ. Factors associated with early and late failure of dental implants. J Investig Clin Dent. 2012;3:258-261. doi:10.1111/j.2041-1626.2012.00162.x

2. Setzer F, Kim S. Comparison of long-term survival of implants and endodontically treated teeth. J Dent Res. 2014;93:19-26. doi:10.1177/ 0022034513504782

3. Moraschini V, Poubel L, Ferreira V, et al. Evaluation of survival and success rates of dental implants reported in longitudinal studies with a follow-up period of at least 10 years: a systematic review. Int $J$ Oral Maxillofac Surg. 2015;44:377-388. doi:10.1016/j.ijom.2014.10.023

4. Lindhe J, Meyle J; Group D of the European Workshop on Periodontology. Peri-implant diseases: consensus report of the sixth european workshop on periodontology. $J$ Clin Periodontol. 2008;35:282-285. doi:10.1111/j.1600-051X.2008.01283.x
5. Schrott AR, Jimenez M, Hwang J, et al. Five-year evaluation of the influence of keratinized mucosa on peri-implant soft-tissue health and stability around implants supporting full-arch mandibular fixed prostheses. Clin Oral Implants Res. 2009;20:1170-1177. doi:10.1111/ j.1600-0501.2009.01795.x

6. Pesce P, Canullo L, Grusovin MG, et al. Systematic review of some prosthetic risk factors for periimplantitis. $J$ Prosthet Dent. 2015;114:346-350. doi:10.1016/j.prosdent.2015.04.002

7. Mir-Mari J, Mir-Orfila P, Figueiredo R, et al. Prevalence of periimplant diseases. A cross-sectional study based on a private practice environment. J Clin Periodontol. 2012;39:490-494. doi:10.1111/ j.1600-051X.2012.01872.x

8. Berglundh T, Armitage G, Araujo MG, et al. Peri-implant diseases and conditions: consensus report of workgroup 4 of the 2017 world workshop on the classification of periodontal and Peri-Implant diseases and conditions. $J$ Periodontol. 2018;89:S313-S318. doi:10.1002/JPER.17-0739

9. Hashim D, Cionca N. A comprehensive review of peri-implantitis risk factors. Curr Oral Health Rep. 2020;7:1-12. doi:10.1007/ s40496-020-00274-2

10. Monje A, Insua A, Wang H. Understanding peri-implantitis as a plaque-associated and site-specific entity: on the local predisposing factors. J Clin Med. 2019;8:279. doi:10.3390/jcm8020279

11. Dawood A, Marti BM, Tanner S. Peri-implantitis and the prosthodontist. $B r$ Dent $J$. 2017;223:325-332. doi:10.1038/sj. bdj. 2017.755

12. Konstantinidis IK, Kotsakis GA, Gerdes S, et al. Cross-sectional study on the prevalence and risk indicators of peri-implant diseases. Eur J Oral Implantol. 2015;8:75-88.

13. Schwarz F, Derks J, Monje A, et al. Peri-implantitis. J Clin Periodontol. 2018;45:S246-S266. doi:10.1111/jcpe.12954

14. Lang NP, Adler R, Joss A, et al. Absence of bleeding on probing an indicator of periodontal stability. $J$ Clin Periodontol. 1990;17:714-721. doi:10.1111/j.1600-051X.1990.tb01059.x

15. Mombelli A, Van Oosten M, Schürch E Jr, et al. The microbiota associated with successful or failing osseointegrated titanium implants. Oral Microbiol Immunol. 1987;2:145-151. doi:10.1111/ j.1399-302X.1987.tb00298.x

16. Smith R, Lath D, Rawlinson A, et al. Gingival inflammation assessment by image analysis: measurement and validation. Int J Dent Hyg. 2008;6:137-142. doi:10.1111/j.1601-5037.2008.00294.x

17. Beagle JR. Developing keratinized mucosa around nonsubmerged dental implants. part I: the use of vascularized flaps. Periodontal Pract Today. 2005;2:13-22.

18. Albrektsson T, Isidor F. Consensus report: implant therapy. In: Lang NP, Karring T, editors.; 1994:365-369.

19. Zafar MS, Fareed MA, Riaz S, et al. Customized therapeutic surface coatings for dental implants. Coatings. 2020;10:1-36. doi:10.3390/ coatings 10060568

20. Najeeb S, Siddiqui F, Khurshid Z, et al. Effect of bisphosphonates on root resorption after tooth replantation-a systematic review. Dent Traumatol. 2017;33:77-83. doi:10.1111/edt.12316

21. Zafar MS, Farooq I, Awais M, Najeeb S, Khurshid Z, Zohaib S. Chapter 11 - bioactive surface coatings for enhancing osseointegration of dental implants; 2019:313-329.

22. Najeeb S, Khurshid Z, Zohaib S, et al. Bioactivity and osseointegration of PEEK are inferior to those of titanium-A systematic review. $J$ Oral Implantol. 2016;42:512-516. doi:10.1563/aaid-joi-D-16-00072

23. Katafuchi M, Weinstein BF, Leroux BG, et al. Restoration contour is a risk indicator for peri-implantitis: a cross-sectional radiographic analysis. J Clin Periodontol. 2018;45:225-232. doi:10.1111/ jcpe. 12829

24. Gerber J, Tan W, Balmer T, et al. Bleeding on probing and pocket probing depth in relation to probing pressure and mucosal health around oral implants. Clin Oral Implants Res. 2009;20:75-78. doi:10.1111/j.1600-0501.2008.01601.x 
25. French D, Nadji N, Larjava H. Survival and success rates of short straumann implants placed in the mandible: a retrospective study with up to 5 year follow-up. Glob J Oral Sci. 2015;1:1-8. doi:10.30576/2414-2050.2015.01.1

26. Buser D, Janner SF, Wittneben J, et al. 10-year survival and success rates of 511 titanium implants with a sandblasted and acid-etched surface: a retrospective study in 303 partially edentulous patients. Clin Implant Dent Relat Res. 2012;14:839-851. doi:10.1111/j.17088208.2012.00456.x

27. Van Velzen FJ, Ofec R, Schulten EA, et al. 10-year survival rate and the incidence of peri-implant disease of 374 titanium dental implants with a SLA surface: a prospective cohort study in 177 fully and partially edentulous patients. Clin Oral Implants Res. 2015;26:1121-1128. doi:10.1111/clr.12499

28. Stoker G, van Waas R, Wismeijer D. Long-term outcomes of three types of implant-supported mandibular overdentures in smokers. Clin Oral Implants Res. 2012;23:925-929. doi:10.1111/j.16000501.2011.02237.x

29. Weber HP, Kim DM, Ng MW, et al. Peri-implant soft-tissue health surrounding cement-and screw-retained implant restorations: a multicenter, 3-year prospective study. Clin Oral Implants Res. 2006;17:375-379. doi:10.1111/j.1600-0501.2005.01232.x

30. Dalago HR, Schuldt Filho G, Rodrigues MAP, et al. Risk indicators for peri-implantitis. A cross-sectional study with 916 implants. Clin Oral Implants Res. 2017;28:144-150. doi:10.1111/clr.12772

31. Wilson TG Jr. The positive relationship between excess cement and peri-implant disease: a prospective clinical endoscopic study. J Periodontol. 2009;80:1388-1392. doi:10.1902/jop.2009.090115

32. Lin G, Chan H, Wang H. The significance of keratinized mucosa on implant health: a systematic review. $J$ Periodontol. 2013;84:1755-1767. doi:10.1902/jop.2013.120688
33. Meffert RM, Langer B, Fritz ME. Dental implants: a review. J Periodontol. 1992;63:859-870. doi:10.1902/jop.1992.63.11.859

34. Gobbato L, Avila-Ortiz G, Sohrabi K, et al. The effect of keratinized mucosa width on peri-implant health: a systematic review. Int J Oral Maxillofac Implants. 2013;28:1536-1545. doi:10.11607/jomi.3244

35. Brito C, Tenenbaum HC, Wong BK, et al. Is keratinized mucosa indispensable to maintain peri-implant health? A systematic review of the literature. $J$ Biomed Mater Res B Appl Biomater. 2014;102:643-650. doi:10.1002/jbm.b.33042

36. Wennström JL, Derks J. Is there a need for keratinized mucosa around implants to maintain health and tissue stability? Clin Oral Implants Res. 2012;23:136-146. doi:10.1111/j.16000501.2012.02540.x

37. Souza AB, Tormena M, Matarazzo F, et al. The influence of periimplant keratinized mucosa on brushing discomfort and peri-implant tissue health. Clin Oral Implants Res. 2016;27:650-655. doi:10.1111/ clr. 12703

38. Bengazi F, Botticelli D, Favero V, et al. Influence of presence or absence of keratinized mucosa on the alveolar bony crest level as it relates to different buccal marginal bone thicknesses. an experimental study in dogs. Clin Oral Implants Res. 2014;25:1065-1071. doi:10.1111/clr.12233

39. van Eekeren P, van Elsas P, Tahmaseb A, et al. The influence of initial mucosal thickness on crestal bone change in similar macrogeometrical implants: a prospective randomized clinical trial. Clin Oral Implants Res. 2017;28:214-218. doi:10.1111/clr.12784
Journal of Multidisciplinary Healthcare

\section{Publish your work in this journal}

The Journal of Multidisciplinary Healthcare is an international, peerreviewed open-access journal that aims to represent and publish research in healthcare areas delivered by practitioners of different disciplines. This includes studies and reviews conducted by multidisciplinary teams as well as research which evaluates the results or conduct of such teams or healthcare processes in general. The journal covers a very wide range of areas and welcomes submissions from practitioners at all levels, from all over the world. The manuscript management system is completely online and includes a very quick and fair peer-review system. Visit http://www.dovepress.com/testimonials. php to read real quotes from published authors. 